\title{
AN INVESTIGATION INTO THE ADOPTION AND ADAPTATION OF THE ENGLISH LOAN WORDS SWAP AND SPREAD IN ROMANIAN AND POLISH TRANSLATIONS OF ECONOMIC DOCUMENTS
}

\author{
Vladislav Mackevic \\ mackeviv@aston.ac.uk \\ Aston University \\ Luciana Sabina Tcaciuc \\ sabina.luciana@gmail.com \\ Aston University
}

\begin{abstract}
This paper identifies strategies for the adoption and adaptation of English loan words in economic documents translated from English into Polish and Romanian at the European Central Bank (ECB), using the terms swap and spread as examples. The economic vocabulary in the Polish and Romanian languages is much less developed than in English, the international language of finance and economics. Therefore, new European terms related to capitalism and the market economy pose a challenge to translators. Polish and Romanian tend to borrow English economic terms due to their novelty and the lack of a well-established economic vocabulary in these two languages. Creative, morphological adaptation is also employed in both languages, as are additional, explanatory words. However, Polish seems to be slightly more conservative - rather than adopting the English term, the Polish language versions contain more instances of the term spread being translated into Polish.
\end{abstract}

\section{Résumé}

Cette étude se propose d'identifier les stratégies d'adoption et d'adaptation des mots empruntés de l'anglais dans des documents économiques traduits de l'anglais au polonais et au roumain à la Banque centrale européenne (BCE), utilisant les termes swap et spread comme des exemples. Le vocabulaire économique du roumain et du polonais est moins développé que celui de l'anglais, la langue internationale des finances et 
des affaires. Par conséquent, les nouveaux termes liés au capitalisme et l'économie de marché représentent un défi pour les traducteurs. Il a été observé que le polonais et le roumain ont la tendance d'emprunter des termes économiques anglais à cause de leur nouveauté et l'absence d'un vocabulaire bien-établi dans ces deux langues. Ladaptation créative, morphologique et l'addition de mots explicatifs sont aussi utilisées dans les deux langues. Cependant, le polonais semble un peu plus conservateur - au lieu d'adopter l'expression anglaise, l'expression polonaise équivalente pour le terme spread est employée plus fréquemment dans les textes polonais.

Keywords: European Central Bank. Loan words. Translating economic terms. Polish. Romanian.

Mots clés : Banque Centrale Européenne. Emprunts. Traduction de termes économiques. Polonais. Roumain.

Manuscript received on June 30, 2015 and accepted for publication on October 26, 2015. 


\section{Introduction}

As the international language of economics, banking and finance, English influences other languages, which borrow economic terms from it. This trend can be noticed in languages that do not have rich economic vocabularies or a longstanding history of developing economic terminology, such as the languages of new EU member states, which had been governed by the rules of a planned economy under Communist regimes. Two prime examples are Poland and Romania, both large countries and thus economically important member states of the EU. When the two countries joined the EU, Poland in 2004 and Romania in 2007, a considerable amount of EU legislation had to be translated from English into the languages of these countries. This legislation often contained new concepts, the translation of which posed challenges to translators. One of the fields in which new concepts had to be introduced into the languages was that of economics and finance. Thus, it is not surprising that the documents in this field contain a large number of English loan words, as the concepts were already well-established in the English language. The aim of this paper is to investigate the adoption and adaptation of English loan words in Polish and Romanian translations of documents published by the European Central Bank (ECB). We decided to focus on both languages because we found that it would be useful to provide a comparison between two languages of two Eastern European former communist countries. Two loan words that frequently occur in the corpus used for this study - the economic terms spread and swap - are examined to identify adoption and adaptation strategies. The study employs mixed research methods, combining quantitative corpus analysis (the number of concordances and collocations) with qualitative examination of parallel translated texts. 


\section{Research Background}

\subsection{English Loan Words in Polish and Romanian}

Loan words are a common linguistic phenomenon that occurs in languages due to language contact and the introduction of new concepts from other cultures. Militaru (2008: 68) defines a loan word thus:

A loanword (or loan word) is a word directly taken into one language from another with little or no translation. By contrast, a calque or loan translation is a related concept whereby it is the meaning or idiom that is borrowed rather than the lexical item itself [...] Loanwords can also be called borrowings.

Loan words are required when the receptor language lacks a word to express a certain notion or concept, especially in fields that evolve rapidly such as IT, technical fields, finance, etc. In both Polish and Romanian, English loan words exist in a variety of domains. The presence of a large number of English loan words had been noticed by a number of scholars, such as, among others, Militaru (2008), Rus (2005), Trăistaru (2008), etc. for Romanian, and Kochman-Haładyj (2001), Kulesza (2010), Sztencel, (2009), Witalisz (2006), etc. for Polish.

\subsubsection{English loan words in Polish}

According to previous research, English terms have been entering the Polish language since the $18^{\text {th }}$ century. For instance, Fisiak (1970) identifies 11 groups of English loan words in Polish, the majority of which have come into the language over the last 200 years. The spelling of many words has changed to reflect the pronunciation phonetically. More recent research demonstrates that the number of English loan words in Polish is increasing (KochmanHaładyj 2001; Witalisz 2006).

Kochman-Haładyj (2001) writes that English borrowings can be divided into those whose use seems to be justified because of the lack of an equivalent in Polish and those which are unjustified, being the effect of snobbery and a desire to boast about one's knowledge of English. She proceeds to argue that if there is a short and simple equivalent (usually only one word), then the English term is not needed. However, when the Polish translation is lengthy and looks more like a definition, adopting an English term is a good solution.

The list of 11 categories identified by Fisiak (1970), with examples, is presented below:

1. Sports and games: sprint, autsajder (outsider), stayer, joker, bokser (boxer) 
2. Maritime terms: dreadnought, lajner (liner), steward, brekwater (breakwater)

3. Economy and trade: biznes (business), boom, import, dumping, freetrade, lend-lease, supermarket, czek (cheque)

4. Science and technology: fading, koks (coke), plastyk (plastic)

5. Transport: klakson (klaxon), starter, wagon, motel

6. Man and society: chuligan (hooligan), lady, landlord

7. Food and drink: barman, lunch, cocktail

8. Fashion: jersey, khaki, mackintosh

9. Arts and culture: dansing (dancing), dubbing, interview

10. Political life: commonwealth, werdykt (verdict), rewolwer (revolver)

11. Agriculture: dren (drain), farma (farm), kombajn (combine)

Witalisz (2006) also describes similar categories; however, her research focuses not only on language but also on aspects of culture, cultural phenomena that loan words bring into the language. Her research examines terms related to the culture of business, economic success, new jobs that appear as working patterns shift and new technologies emerge, etc. Yet, 36 years after Fisiak (1970), Witalisz also notices that the number of economic and business terms in Polish is increasing. Therefore, one could speak about a longitudinal trend.

\subsubsection{English loan words in Romanian}

English borrowings have existed in the Romanian language for about 150 years. These words receive a grammatical gender and are used according to the rules of the Romanian language. Trăistaru (2008) argues that the number of terms borrowed from English is increasing, especially in fields like economics, administration, commerce and IT. Trăistaru (2008: 721-722) classifies English loan words into the following categories, according to the field:

1. Economic, financial, commercial terminology: staff, management, lobby, discount, dumping, broker, dealer.

2. IT terminology: mouse, chat, software, online.

3. Music terminology: playback, hit, single.

4. Sport terminology: baseball, bungee jumping, fitness.

5. Food terminology: hamburger, fast-food, hot dog.

6. Fashion and cosmetics terminology: look, lifting, make-up.

As could be noticed from the examples above, the English words from Trăistaru's (2008) list are not transliterated, unlike the Polish examples from 
Fisiak's (1970) list and Witalisz's (2006) research. This may suggest that English loan words are more easily introduced into the Romanian language without adaptation in spelling, while the Polish language requires adaptation in spelling because of the phonetic rules of the language.

\subsection{Strategies for the adoption of English loan words}

In her paper on the influence of English in Polish legalese, WięcławskaSzymańska (2009) provides numerous examples of economic and business terms entering the Polish language. She writes that the "process of borrowing cannot take place on one language level exclusively" (Więcławska-Szymańska, 2009: 41). She argues that every time a new loan word comes into contact with the receptor language, it undergoes a process of integration "which means that foreign items are substituted with the native forms or native forms are added to them" (Więcławska-Szymańska, 2009: 41). There are various strategies for the adaptation of loan words in Polish and Romanian. Manea (2005: 366) identifies several ways of adapting loan words:

1. Adaptation in point of form

a. Spelling. English words preserve the original spelling (e.g. spread and swap in this study). Due to the spelling conventions in Polish and Romanian, there are also morphological implications: endings are added to the words as required by the grammar. For instance, in Romanian, forms like spread-ul ('the spread'), spreaduri (the plural form 'spreads'), swap-uri (the plural form 'swaps'), swap-urile ('the swaps') appear, in which the English stem and the Romanian inflectional mark are brought together, by means of a hyphen. Another category consists of the rather infrequent cases of solid spelling, e.g. swapuri, spreaduri: these terms are obviously considered as fully adapted loans. In Polish, inflections are used, e.g. to form the plural (swapy - 'swaps', spready - 'spreads') or to make an adjectival form (swapowy, swapowych, which, loosely translated, means 'of the swap type', usually referring to transactions).

b. Phonology. Borrowings can often be adapted to the pronunciation and grammar of the language. One example of adapting an English loan word while altering its spelling is the word match (the sports term), which in Romanian is translated as meci and in Polish as mecz (both languages adapted the spelling in order for the word to be pronounced as in English). 
2. Morphological adaptation

Morphological adaptation means adding the inflectional markers specific to the nominal category (e.g., Polish and Romanian inflectional endings or the Romanian definite article, or even changing the word class). For example, in the Romanian economic vocabulary the terms hedgingul, leadershipul, clearingul are English words with the definite article attached at the end. Manea (2005) and Więcławska-Szymańska (2009) demonstrate that English loan words are being adapted to the morphological, i.e. grammatical, specificity of the Romanian and Polish languages. This study has also found evidence of this (see above on inflections at the end of the English words).

3. Adding explanatory words

Another way to integrate non-inflected words into the receptor language is by adding other words to the term that act as explanatory words. In the present study, it was found that the most common way to make the English term sound more natural was by adding the word transakcje ('transactions') in Polish and operațiuni ('operations') in Romanian to the term swap.

\subsection{Poland and Romania}

We find that it is important to explain why we have chosen to focus on these two languages in particular. First of all, Poland and Romania represent a very specific setting in the EU. Both are new EU countries (Poland joined in 2004 and Romania in 2007); both are former communist countries that entered the global marketplace in the early 1990s. One could presume that the majority of the vocabulary related to international business, free market economics, banking and finance entered both languages at that time. Therefore, since the prior exposure of these countries to the language of business had been limited, it is very interesting to observe how the Polish and Romanian languages have adopted new terminology, the majority of which first appeared in English.

\subsection{Research questions}

This study aims to answer the following questions:

1. What strategies do translators of documents at the European Central Bank employ to adopt and adapt English economic terms into Polish and Romanian? 
2. How do these strategies relate to what is discussed in the literature on loan word adoption and adaptation?

\section{Methodology}

\subsection{The dataset}

The corpus used in this research study consists of 24 texts. The three subcorpora for each language version (English, Polish and Romanian) comprise eight texts each. The texts selected for analysis are the ECB's annual reports (AR) dating from 2006 to 2013. There are several reasons for the selection of these texts. Firstly, the texts produced at the European Central Bank are prime examples of economic and institutional translation (although they are not referred to as translations but as language versions). Secondly, the EU institutions create a unique research environment for translation studies because their documents are publicly available in 24 official languages. Finally, EU documents are long and comprehensive (each document is at least 86,000 words long, with the longest one containing over 128,000 words) and can provide numerous examples of translation challenges as well as allowing one to observe how different translation strategies changed over time. Table 1 below summarises the information about the subcorpora. As ECB documents contain a large number of figures, these were removed from the subcorpora and the figures in the table represent only tokens written in alphabetic (non-numeric) characters.

\begin{tabular}{|c|c|c|c|}
\hline & \multicolumn{3}{|c|}{ Language } \\
\hline Document & EN & PL & RO \\
\hline AR 2006 & 99,673 & 90,723 & 106,237 \\
\hline AR 2007 & 107,590 & 100,295 & 116,557 \\
\hline AR 2008 & 118,944 & 111,171 & 128,540 \\
\hline AR 2009 & 110,981 & 104,300 & 120,546 \\
\hline AR 2010 & 111,658 & 103,710 & 122,106 \\
\hline AR 2011 & 86,236 & 87,834 & 105,668 \\
\hline AR 2012 & 89,517 & 91,110 & 109,002 \\
\hline AR 2013 & 97,559 & 107,050 & 127,580 \\
\hline TOTAL & 822,158 & 796,193 & 936,236 \\
\hline
\end{tabular}

Table 1. Summary of subcorpus sizes for English, Polish and Romanian. 


\subsection{Research methods}

It was decided to employ mixed research methods for this study: quantitative research was combined with qualitative research. Quantitative research comprised corpus analysis: word frequencies, collocation analysis (examining words that frequently occur together), as well as n-grams, or word clusters. The rationale for using mixed methods was that using quantitative analysis alone would cause the findings to lack depth because numbers and raw frequencies would not provide sufficient information on trends over time or on developments within documents. Analysing some more unusual examples more closely would allow the researchers to see a bigger picture.

The English loan words chosen for this article were SPREAD and SWAP. They were chosen because they appear as loan words in both the Polish and Romanian language versions and because they are relatively frequent words in the three subcorpora (see Table 2 in section 4.1 below).

\section{Analysis and discussion}

\subsection{Quantitative analysis}

This section presents the results of the quantitative analysis. The frequencies of the terms SPREAD and SWAP, as well as the frequencies of the collocations and n-grams (word clusters) containing these expressions have been calculated. The results are presented below.

\begin{tabular}{|c|c|c|c|c|c|c|}
\hline & \multicolumn{3}{|c|}{ SPREAD* } & \multicolumn{3}{|c|}{ SWAP* } \\
\hline & EN & PL & $\mathrm{RO}$ & EN & PL & RO \\
\hline AR 2006 & 43 & $3 *(1)$ & 31 & 14 & 14 & 15 \\
\hline AR 2007 & 51 & 1 & 41 & 36 & 35 & 39 \\
\hline AR 2008 & 60 & 18 & 47 & 87 & 85 & 79 \\
\hline AR 2009 & 81 & 48 & 86 & 110 & 111 & 104 \\
\hline AR 2010 & 40 & 6 & 37 & 78 & 67 & 78 \\
\hline AR 2011 & 19 & 3 & 13 & 52 & 50 & 50 \\
\hline AR 2012 & 22 & 4 & 18 & 57 & 44 & 53 \\
\hline AR 2013 & 10 & 2 & 8 & 57 & 50 & 54 \\
\hline TOTAL & 275 & 85 & 281 & 491 & 456 & 472 \\
\hline $\begin{array}{c}\text { TOTAL FREQ. PER } \\
100,000 \text { WORDS }\end{array}$ & 31.26 & 10.68 & 30.01 & 59.72 & 57.27 & 50.41 \\
\hline
\end{tabular}

Table 2. Frequencies of the terms spread* and swap* in all their morphological forms in the three subcorpora. 
4.1.1 The terms swap and spread in Polish language versions SPREAD

Table 2 above reveals some interesting findings. First of all, the term spread occurs much less frequently in the Polish subcorpus than in the Romanian one. In fact, the Polish texts favour a literal translation of the word (rozpiętość), which could even be called a calque, fitting in with the definition provided above by Militaru (2008). For instance, the phrases the spread/spreads between (EN 34 times) and rozpietość/rozpietości pomiedzy (PL 25 times) are literal equivalents, and so are bond yield spreads (EN 22 times) and rozpietości rentowności/oprocentowania obligacji (PL 14 times). For a comparison between the collocations of the English spread and the Polish rozpiętość, see Tables 3 and 4 below.

\begin{tabular}{|c|c|c|c|c|c|}
\hline \multicolumn{3}{|c|}{ EN subcorpus } & \multicolumn{3}{|c|}{ PL subcorpus } \\
\hline $\mathrm{N}$ & Cluster & Freq. & $\mathrm{N}$ & Cluster & Freq. \\
\hline 1 & THE SPREAD BETWEEN & 25 & 1 & $\begin{array}{l}\text { OBLIGACJI SKARBOWYCH } \\
\mathrm{W}\end{array}$ & 11 \\
\hline 2 & SPREAD BETWEEN THE & 25 & 2 & $\begin{array}{l}\text { ROZPIETOSCI } \\
\text { RENTOWNOSCI } \\
\text { OBLIGACJI }\end{array}$ & 9 \\
\hline 3 & BOND YIELD SPREADS & 22 & 3 & $\begin{array}{l}\text { STRONIE ROZPIETOSC } \\
\text { POMIEDZY }\end{array}$ & 8 \\
\hline 4 & $\begin{array}{l}\text { GOVERNMENT BOND } \\
\text { YIELD }\end{array}$ & 15 & 4 & SKALA PO LEWEJ & 8 \\
\hline 5 & THE EURO AREA & 14 & 5 & PO LEWEJ STRONIE & 8 \\
\hline 6 & $\begin{array}{l}\text { MONEY MARKET } \\
\text { SPREADS }\end{array}$ & 11 & 6 & $\begin{array}{l}\text { W PUNKTACH } \\
\text { BAZOWYCH }\end{array}$ & 8 \\
\hline 7 & EURO AREA SOVEREIGN & 11 & 7 & $\begin{array}{l}\text { LEWEJ STRONIE } \\
\text { ROZPIETOSC }\end{array}$ & 8 \\
\hline 8 & SPREADS IN THE & 11 & 8 & $\begin{array}{l}\text { ROZPIETOSC POMIEDZY } \\
\text { 3-MIESIECZNA }\end{array}$ & 7 \\
\hline 9 & THE SPREADS BETWEEN & 9 & 9 & $\begin{array}{l}\text { 3-MIESIECZNA STOPA } \\
\text { EURIBOR }\end{array}$ & 7 \\
\hline 10 & $\begin{array}{l}\text { TWELVE-MONTH AND } \\
\text { ONE-MONTH }\end{array}$ & 9 & 10 & $\begin{array}{l}\text { POMIEDZY } \\
\text { 3-MIESIECZNA STOPA }\end{array}$ & 7 \\
\hline 11 & $\begin{array}{l}\text { CORPORATE BOND } \\
\text { SPREADS }\end{array}$ & 8 & 11 & $\begin{array}{l}\text { RENTOWNOSCI } \\
\text { OBLIGACJI SKARBOWYCH }\end{array}$ & 7 \\
\hline 12 & $\begin{array}{l}\text { SOVEREIGN BOND } \\
\text { SPREADS }\end{array}$ & 8 & 12 & STOPA EURIBOR A & 7 \\
\hline
\end{tabular}


An investigation into the adoption and adaptation of the English loan words swap... 169

\begin{tabular}{|c|l|c|c|l|c|}
\hline 13 & SCALE SPREAD BETWEEN & 8 & 13 & $\begin{array}{l}\text { POMIEDZY } \\
\text { l2-MIESIECZNA A }\end{array}$ & 5 \\
\hline 14 & $\begin{array}{l}\text { EURO AREA } \\
\text { GOVERNMENT }\end{array}$ & 8 & 14 & $\begin{array}{l}\text { I ROZPIETOSC } \\
\text { RENTOWNOSCI }\end{array}$ & 5 \\
\hline 15 & $\begin{array}{l}\text { LEFT-HAND SCALE } \\
\text { SPREAD }\end{array}$ & 8 & 15 & $\begin{array}{l}\text { ROZPIETOSC POMIEDZY } \\
\text { 12-MIESIECZNA }\end{array}$ & 5 \\
\hline 16 & $\begin{array}{l}\text { SECURED AND } \\
\text { UNSECURED }\end{array}$ & 7 & 16 & $\begin{array}{l}\text { ROZPIETOSCI POMIEDZY } \\
\text { STOPAMI }\end{array}$ & 5 \\
\hline 17 & SPREADS BETWEEN THE & 7 & 17 & $\begin{array}{l}\text { ROZPIETOSCI } \\
\text { OPROCENTOWANIA } \\
\text { OBLIGACJI }\end{array}$ & 5 \\
\hline
\end{tabular}

Table 3. Trigrams with the expression spread and rozpietosc in the English and Polish subcorpora

As it can be observed from Table 1, the English term spread is not fully integrated into the Polish language versions. However, when it is, an interesting trend can be observed: the word spread is adapted to the rules of the Polish language by adding case inflections (e.g. spready - the plural form; spreadów - plural Genitive case; spreadu - singular Genitive case; spreadach - plural Instrumental case).

\begin{tabular}{|c|l|c|c|}
\hline $\mathbf{N}$ & \multicolumn{1}{|c|}{ Word } & Texts & Total \\
\hline 11 & SPREADY & 6 & 28 \\
\hline 2 & SPREADÓW & 5 & 24 \\
\hline 5 & SPREADS & 3 & 14 \\
\hline 6 & SPREAD & 5 & 13 \\
\hline 37 & SPREADU & 2 & 3 \\
\hline 60 & SPREADACH & 2 & 2 \\
\hline
\end{tabular}

Table 4. Adaptation of the term SPREAD in the Polish subcorpus

SWAP

From the isolated example of SPREAD, it might seem that Polish is rather conservative, much less willing to accept English loan words, rather preferring to invent a translation or to 'Polonise' the term through a calque. However, one sees a different picture when looking at the term swap. The table below shows how the term swap behaves in Polish texts. The English word swap is left unchanged in 171 out of 456 cases, or $37.5 \%$. However, the term is not provided on its own in all of these instances. In 121 out of 456 instances 
(26.54\%), the explanatory term transakcje/transakcji/transakcjami ('transactions' in different cases) is added before it in order to make the meaning of the new term clearer. Therefore, the term appears on its own only in $10.96 \%$ of all instances or 50 times. Moreover, to accommodate the English term in the Polish language, typical Polish inflections are attached to it to signify morphological changes: swapa//swapów ('of the swap/swaps'); swapy ('swaps' - plural); swapach (various instances of the prepositional case); swapami (various instances of the instrumental case). The total number of instances with such morphological changes is 219 , or $48.03 \%$. An even more interesting linguistic development is turning the word into an adjective and inflecting it according to the case in which it is used: swapowa / swapowe / swapowej / swapowymi / swapowych. This strategy is encountered 61 times or in 13.38\% of all instances of use. Witalisz (2006) reports that that many loan words and neologisms undergo such changes. Więcławska-Szymańska (2009) also writes that such a strategy is commonly used in Polish to adapt foreign terms.

It is interesting to observe that the term swap appears in the same documents as the term spread, yet the latter was adopted slowly and a literal translation into Polish was preferred. However, the term swap is actively used, and appears both in its unchanged form and with morphological endings as early as 2006; the adjectival form swapow* is also encountered as early as 2007 . See Table 5 below for more details.

\begin{tabular}{|l|l|l|c|c|c|c|c|}
\hline $\mathbf{N}$ & \multicolumn{1}{|c|}{ Word } & \multicolumn{1}{|c|}{ With } & Texts & Total & Ll & Centre & R1 \\
\hline 1 & SWAP & swap & 8 & 171 & & 171 & \\
\hline 2 & SWAPÓW & swapów & 8 & 130 & & 130 & \\
\hline 5 & SWAPY & swapy & 8 & 64 & & 64 & \\
\hline 6 & TRANSAKCJE & swap & 8 & 62 & 57 & & \\
\hline 8 & TRANSAKCJI & swap & 7 & 53 & 46 & & \\
\hline 9 & WALUTOWYCH & swapów & 8 & 50 & & & 39 \\
\hline 15 & PROCENTOWYCH & swapów & 8 & 32 & & & 31 \\
\hline 21 & WALUTOWE & swapy & 8 & 27 & & & 21 \\
\hline 24 & PROCENTOWE & swapy & 7 & 24 & & & 20 \\
\hline 30 & SWAPOWYCH & swapowych & 5 & 17 & & 17 & \\
\hline 32 & BACK-TO-BACK & swap & 6 & 17 & & & 10 \\
\hline 36 & LINII & swap & 6 & 15 & 15 & & \\
\hline 37 & WYCENY & swapów & 8 & 15 & 5 & & \\
\hline 39 & SWAPOWEJ & swapowej & 5 & 14 & & 14 & \\
\hline
\end{tabular}




\begin{tabular}{|l|l|l|c|c|c|c|c|}
\hline 43 & LINIE & swap & 7 & 14 & 14 & & \\
\hline 47 & RYZYKA & swapów & 4 & 13 & & & 13 \\
\hline 51 & OTWARTYCH & swapów & 5 & 13 & 11 & & \\
\hline 52 & SWAPACH & swapach & 6 & 13 & & 13 & \\
\hline 53 & SWAPOWE & swapowe & 5 & 13 & & 13 & \\
\hline 55 & SWAPOWA & swapowa & 7 & 13 & & 13 & \\
\hline
\end{tabular}

Table 5. Adaptation of the English term SWAP in the Polish subcorpus

4.1.2. Terms swap and spread in Romanian language versions SPREAD

The table below shows how the term spread is introduced in the Romanian language. As noted earlier in this section, the English term is used much more in Romanian than in Polish. However, just as in Polish, the term is adopted and adapted in the language. The English term, uninflected, with its spelling unchanged, is not used very frequently: spread/spreads appears 28 times $(9.96 \%)$, yet only 12 of these (4.27\% of all instances) are actually used in the Romanian translation. The other instances (one spread and 15 spreads) are all found in titles of publications. In the majority of instances (253 cases or 90.03\%), Romanian endings are attached to the English term: spread-ul ('the spread'); spread-ului (genitive/dative case); spreaduri / spread-uri ('spreads' plural); spreadurile / spread-urile ('the spreads'); spreadurilor / spread-urilor (plural genitive/dative case). Therefore, just as in Polish, the term is integrated into the language. In fact, it is integrated much more actively than in Polish: the differences in the spelling of these endings indicate the process of searching for the right form. Most of them are hyphenated (90.91\% of all cases with endings) although the remainder are not $(9.09 \%)$. Concordance analysis reveals that hyphenated forms, albeit rare, appear in texts dating from 2006 to 2010, but not in later ones. However, as the examples from the qualitative analysis will show, different forms were used simultaneously in the past.

\begin{tabular}{|l|l|c|c|c|}
\hline \multicolumn{1}{|c|}{ Word } & \multicolumn{1}{|c|}{ Texts } & Total & Centre \\
\hline 1 & SPREAD-URILE & 8 & 85 & 86 \\
\hline 2 & SPREAD-URILOR & 6 & 62 & 60 \\
\hline 3 & SPREAD-UL & 8 & 61 & 60 \\
\hline 8 & OBLIGATIUNILOR & 7 & 27 & \\
\hline 16 & SPREADS & 3 & 19 & 15 \\
\hline
\end{tabular}




\begin{tabular}{|l|l|c|c|c|}
\hline 22 & SPREADURILE & 5 & 15 & 15 \\
\hline 29 & SPREAD & 7 & 13 & 13 \\
\hline 33 & SPREAD-ULUI & 6 & 13 & 13 \\
\hline 41 & CDS & 6 & 12 & \\
\hline 43 & SPREAD-URI & 5 & 11 & 11 \\
\hline 89 & SPREADURILOR & 4 & 6 & 6 \\
\hline 216 & SPREADURI & 2 & 2 & 2 \\
\hline
\end{tabular}

Table 6. The distribution of the loanword SPREAD in the Romanian subcorpus

\section{SWAP}

As discussed above, both English terms SPREAD and SWAP seem to have been adopted very naturally in the Romanian language versions of the texts. However, as the analysis in this section will show, the term SWAP is translated differently from the term SPREAD. The tables below show how the term swap behaves in Romanian translations.

\begin{tabular}{|l|l|c|}
\hline \multicolumn{1}{|c|}{ N Cluster } & \multicolumn{1}{|c|}{ Freq. } \\
\hline 1 & DE SWAP VALUTAR & 160 \\
\hline 2 & OPERATIUNI DE SWAP & 93 \\
\hline 3 & OPERATIUNILOR DE SWAP & 81 \\
\hline 4 & PE RATA DOBÂNZII & 72 \\
\hline 5 & LA TERMEN SI & 56 \\
\hline 6 & SWAP PE RATA & 38 \\
\hline 7 & SWAP VALUTAR SI & 35 \\
\hline 16 & SWAP VALUTAR ÎN & 21 \\
\hline 17 & SWAP VALUTAR ACESTE & 20 \\
\hline 18 & CU CARACTER TEMPORAR & 20 \\
\hline 19 & LINIE DE SWAP & 19 \\
\hline 20 & OPERATIUNILE DE SWAP & 19 \\
\hline 31 & AFERENTE OPERATIUNILOR SWAP & 12 \\
\hline 32 & SWAP CU CARACTER & 12 \\
\hline 33 & LINII DE SWAP & 12 \\
\hline 40 & SI RATELE SWAP & 11 \\
\hline 43 & EXCHANGE SWAP TRANZACTII & 10 \\
\hline 46 & FOREIGN EXCHANGE SWAP & \\
\hline & & \\
\hline
\end{tabular}


An investigation into the adoption and adaptation of the English loan words swap... 173

\begin{tabular}{|l|l|l|}
\hline 47 & OPERATIUNILOR SWAP INDEXATE & 10 \\
\hline 51 & SWAP-URILOR PE RATA & 10 \\
\hline 52 & SWAP-URI VALUTARE FOREIGN & 10 \\
\hline
\end{tabular}

Table 7. The distribution of the loanword SWAP in the Romanian subcorpus

\begin{tabular}{|l|l|l|c|c|c|c|c|c|c|}
\hline \multicolumn{1}{|c|}{ N } & \multicolumn{1}{|c|}{ Word } & \multicolumn{1}{c|}{ With } & Texts & Total & L2 & L1 & Centre & R1 & R2 \\
\hline 1 & DE & Swap & 8 & 398 & 1 & 294 & & 1 & 12 \\
\hline 2 & SWAP & Swap & 8 & 388 & & & 388 & & \\
\hline 3 & VALUTAR & Swap & 8 & 178 & & & & 168 & \\
\hline 7 & OPERATIUNILOR & Swap & 8 & 107 & 81 & 24 & & & \\
\hline 8 & OPERATIUNI & Swap & 8 & 99 & 90 & & & & \\
\hline 16 & VALUTARE & Swap & 8 & 48 & & & & & 5 \\
\hline 17 & AFERENTE & Swap & 6 & 42 & 14 & & & & \\
\hline 18 & OPERATIUNILE & Swap & 8 & 29 & 19 & 4 & & & \\
\hline 21 & PARALELE & Swap & 7 & 23 & & & & 23 & \\
\hline 25 & SWAP-URI & swap-uri & 6 & 21 & & & 21 & & \\
\hline 33 & SWAP-URILOR & swap-urilor & 7 & 19 & & & 19 & & \\
\hline 44 & SWAPURILOR & Swapurilor & 4 & 13 & & & 13 & & \\
\hline 66 & SWAPS & Swaps & 6 & 10 & & & 10 & & \\
\hline 83 & SWAPURI & Swapuri & 3 & 9 & & & 9 & & \\
\hline 114 & SWAP-URILE & swap-urile & 5 & 7 & & & 7 & & \\
\hline 171 & SWAP & swap-uri & 5 & 5 & & & & & \\
\hline 173 & SWAP-URI & Swap & 5 & 5 & & & & & \\
\hline 174 & SWAPURILE & Swapurile & 3 & 5 & & & 5 & & \\
\hline
\end{tabular}

Table 8. Collocations of the term SWAP in the Romanian subcorpus

As can be seen from the tables above, in the majority of cases (388 out of 472 , or $82.2 \%$ ), the original English term is kept with its spelling unchanged - i.e. no morphological devices are used. However, just as in Polish, it is complemented by an explicitation: operatiuni ('operations') and its forms (operațiunile, operațiunilor - the plural articulated form 'the operations' and its genitive/dative case). The word operations collocates with the expression swap in phrases like operațiuni de swap, operațiunile/operațiunilor (de) swap 218 times out of 388 , or $56.19 \%$ of all instances of the expression swap. Unlike with the term spread, inflected forms are not widespread in Romanian 
language versions: inflected forms constitute only $10.17 \%$ of all instances, their raw frequency being 48 . As regards hyphenation, the trend seems to be different from that of the term spread. Unlike spread, hyphenated forms of SWAP* occur between 2006 and 2010 but not later, although they are found in more texts than the non-hyphenated versions. Just as with the term SPREAD*, it seems that the translators were searching for appropriate forms, which indicates a dynamic relationship with the texts in the institution. However, there is a tendency towards term fossilisation as time goes by, and institutional uniformity can already be observed. This is in line with the arguments advanced by Koskinen (2008), who writes that the voice of the institution, not the translator, is present in documents translated in institutions. However, the term institution can be understood broadly here: it can also potentially mean the language as an institution, with its strict rules of grammar and integration of foreign words. Finally, with reference to the integration of the terms SWAP and SPREAD, it is important to note that when they are hyphenated, both terms are also italicised in the entire corpus. This meta-linguistic device indicates that both terms are novel in the Romanian language and underlines their foreignness. It is interesting to observe how the hyphen is used as a separator for the italicised and non-italicised parts of the word, emphasising the foreignness of the terms.

There are several possible explanations for such differences between Polish and Romanian subcorpora. One of them is that the Polish language adopts an English word when no direct equivalent can be found (cf. Kochman-Haładyj, 2001) and, hence, swap was adopted and spread was mostly translated into Polish as there was an equivalent. It is possible that the English term spread was adopted so fast in the Romanian language version, even if the texts started being translated later (in 2006, not 2004) because there was no direct equivalent in Romanian and a translation would sound more like a definition.

\subsection{Qualitative analysis}

In this section, more salient examples from the corpus will be analysed in order to gain a deeper insight into the translation strategies employed by ECB translators and to highlight cases of unusual and creative translation within the institutional framework of uniformity. Examples from earlier texts (200609) have been chosen because the translation strategies tend to be less uniform in the texts produced in that period. 
(1) Example 1

\begin{tabular}{|c|c|c|}
\hline EN language version & PL language version & RO language version \\
\hline \multirow[t]{3}{*}{$\begin{array}{l}\text { This is reflected in a } \\
\text { corresponding decline } \\
\text { of the "term spread", } \\
\text { measured by the difference } \\
\text { between the yield on a ten- } \\
\text { year government bond and } \\
\text { the three month EURIBOR. } \\
\text { AR } 2006\end{array}$} & $\begin{array}{l}\text { Tendencję tę widać w } \\
\text { odpowiednim zmniejszeniu } \\
\text { się „rozpiętości } \\
\text { terminowej” (ang. term } \\
\text { spread), mierzonej } \\
\text { rożnicą pomiędzy } \\
\text { rentownością 10-letnich } \\
\text { obligacji skarbowych } \\
\text { a trzymiesięczną stopą } \\
\text { EURIBOR. }\end{array}$ & $\begin{array}{l}\text { Această evoluţie s-a } \\
\text { reflectat în scăderea } \\
\text { corespunzătoare a „spread- } \\
\text { ului dintre scadențe”, } \\
\text { măsurat ca diferenţă } \\
\text { între randamentul unei } \\
\text { obligaţiuni de stat la 10 } \\
\text { ani şi rata EURIBOR la trei } \\
\text { luni. }\end{array}$ \\
\hline & Back Translation & Back Translation \\
\hline & $\begin{array}{l}\text { These trends can } \\
\text { be observed in the } \\
\text { corresponding reduction of } \\
\text { "term spread" (Eng. term } \\
\text { spread), which is measured } \\
\text { as the difference between } \\
\text { the yield of } 10 \text {-year } \\
\text { government bonds and the } \\
\text { three-month EURIBOR } \\
\text { rate. }\end{array}$ & $\begin{array}{l}\text { This development } \\
\text { was reflected in the } \\
\text { corresponding fall of the } \\
\text { "spread between terms" } \\
\text { that is measured as the } \\
\text { difference between the } \\
\text { yield of the } 10 \text {-year state } \\
\text { bond and the three-month } \\
\text { EURIBOR rate. }\end{array}$ \\
\hline
\end{tabular}

Analysis

In this example, the Polish language version contains a translation of the expression term spread („rozpiętości terminowej”) between inverted commas. The English version also uses inverted commas, possibly because the term is new even in English and requires an explanation. It is also interesting that the Polish translator chose to use the English term in brackets. It could be presumed that this was done for the benefit of the readers (specialised audience) as they are more likely to be familiar with the English term.

The Romanian language version also contains inverted commas because the English version does. It also contains the English term spread in the genitive case with the definite article. However, the word spread is not only integrated but also explained as 'the spread between terms'. There is no reference to the English term. This could be because the English term is actually a part of the Romanian term; this would make the translation unnecessary, even for the specialised audience. 
(2) Example 2

\begin{tabular}{|c|c|c|}
\hline EN language version & PL language version & RO language version \\
\hline \multirow[t]{3}{*}{$\begin{array}{l}\text { Signs of deterioration in } \\
\text { market liquidity are also } \\
\text { evident in quoted bid- } \\
\text { ask spreads, which have } \\
\text { widened significantly. } \\
\text { AR } 2008\end{array}$} & $\begin{array}{l}\text { Oznaki pogorszenia } \\
\text { płynności rynku widać w } \\
\text { rozpiętościach pomiędzy } \\
\text { cenami w zleceniach } \\
\text { sprzedaży i cenami w } \\
\text { zleceniach kupna (ang. } \\
\text { quoted bid-ask spreads), } \\
\text { które znacznie się } \\
\text { poszerzyły. }\end{array}$ & $\begin{array}{l}\text { De asemenea, indicii de } \\
\text { deteriorare a lichidităţii pe } \\
\text { aceste piețe s-au manifestat } \\
\text { şi la nivelul marjelor dintre } \\
\text { cotaţiile la vânzare şi cele } \\
\text { la cumpărare, care au } \\
\text { cunoscut o majorare } \\
\text { semnificativă. }\end{array}$ \\
\hline & Back Translation & Back Translation \\
\hline & $\begin{array}{l}\text { Signs of worsening in } \\
\text { market liquidity are seen } \\
\text { in the spreads between the } \\
\text { selling price quotes and } \\
\text { buying price quotes (Eng. } \\
\text { quoted bid-ask spreads), } \\
\text { which have widened } \\
\text { significantly. }\end{array}$ & $\begin{array}{l}\text { The signs of deterioration } \\
\text { of the liquidity in these } \\
\text { markets were also present } \\
\text { at the level of the margins } \\
\text { between selling quotes } \\
\text { and buying quotes, } \\
\text { which have experienced a } \\
\text { significant increase. }\end{array}$ \\
\hline
\end{tabular}

Analysis

Just as in Example 1 above, the Polish language version offers a literal translation of the financial term with the English term provided in brackets. However, unlike in the previous example, the Romanian language version contains a different translation - marje ('margins') instead of a form of the word spread*. This indicates that even in 2008 translators were still searching for an appropriate solution to this translation problem and adds to the argument about the dynamic relationship with the texts and terms at the ECB. 
(3) Example 3

\begin{tabular}{|c|c|c|}
\hline EN language version & PL language version & RO language version \\
\hline \multirow[t]{3}{*}{$\begin{array}{l}\text { BBB-rated corporate } \\
\text { bond spreads fluctuated } \\
\text { around an average of } \\
\text { approximately } 75 \text { basis } \\
\text { points in } \\
2006 . \\
\text { AR } 2006\end{array}$} & $\begin{array}{l}\text { W } 2006 \text { r. rozpiętość } \\
\text { obligacji korporacyjnych } \\
\text { o ratingu BBB oscylowała } \\
\text { wokoł } 75 \text { punktow } \\
\text { bazowych. }\end{array}$ & $\begin{array}{l}\text { Spread-urile associate } \\
\text { obligațiunilor corporative } \\
\text { cu calificativul BBB au } \\
\text { fluctuat în jurul unei medii } \\
\text { de aproximativ } 75 \text { puncte } \\
\text { de bază. }\end{array}$ \\
\hline & Back Translation & Back Translation \\
\hline & $\begin{array}{l}\text { In } 2006, \text { BBB-rated spreads } \\
\text { of corporate bonds } \\
\text { fluctuated around } 75 \text { basis } \\
\text { points. }\end{array}$ & $\begin{array}{l}\text { The spreads related to } \\
\text { the corporate bonds with } \\
\text { the BBB rating fluctuated } \\
\text { around an average of } \\
\text { approximately } 75 \text { basis } \\
\text { points. }\end{array}$ \\
\hline
\end{tabular}

(4) Example 4

\begin{tabular}{|l|l|l|}
\hline \multicolumn{1}{|c|}{ EN language version } & \multicolumn{1}{c|}{ PL language version } & \multicolumn{1}{c|}{ RO language version } \\
\hline $\begin{array}{l}\text { The decline in the net } \\
\text { issuance activity of } \\
\text { nonfinancial corporations } \\
\text { became far more marked } \\
\text { as of August 2007. This } \\
\text { may have been related to } \\
\text { the rise in corporate bond } \\
\text { spreads } \\
\text { AR } 2007\end{array}$ & $\begin{array}{l}\text { od sierpnia 2007 r. spadek } \\
\text { działalności emisyjnej netto } \\
\text { sektora przedsiębiorstw } \\
\text { był o wiele głębszy, co } \\
\text { mogło wynikać ze wzrostu } \\
\text { spreadów dla obligacji } \\
\text { przedsiębiorstw }\end{array}$ & $\begin{array}{l}\text { activitatea de emisiuni nete } \\
\text { a societăţilor nefinanciare } \\
\text { a intrat într-un declin mult } \\
\text { mai pronunțat începând cu } \\
\text { luna august 2007, probabil } \\
\text { pe fondul majorării spread- } \\
\text { urilor obligaţiunilor } \\
\text { corporative }\end{array}$ \\
\hline & $\begin{array}{l}\text { Back Translation } \\
\text { the decline in net issuance } \\
\text { activity of the enterprise } \\
\text { sector was much greater, } \\
\text { which may have been the } \\
\text { effect of the rise in the } \\
\text { spreads for corporate } \\
\text { bonds }\end{array}$ & $\begin{array}{l}\text { Back Translation } \\
\text { of nonfinancial companies } \\
\text { recorded a much more } \\
\text { significant decline } \\
\text { starting from August } \\
\text { 2007, probably due to the } \\
\text { increase in the spreads of } \\
\text { corporate bonds. }\end{array}$ \\
\hline
\end{tabular}

Analysis

Examples 3 and 4 should be analysed together because they reveal different ways to translate the same expression (corporate bond spreads). Both the Polish and the Romanian language versions demonstrate interesting 
differences in the way the expressions were translated in 2006 and 2007. In 2006, the term spread was translated as rozpiętość in the Polish language version. However, the word spreadów (plural, genitive case) is used in the 2007 Annual Report. The presence of these inflections shows that the English term was adopted in the economic vocabulary of the ECB Polish texts but it was not used extensively.

As it can be seen from the Romanian examples, the English term SPREAD is kept but it is italicised to emphasise its foreignness and Romanian inflections are added to adapt the term to the grammatical requirements of the Romanian language.

\section{(5) Example 5}

\begin{tabular}{|c|c|c|}
\hline EN language version & PL language version & RO language version \\
\hline \multirow[t]{3}{*}{$\begin{array}{l}\text { This is illustrated in } \\
\text { Chart B, which shows } \\
\text { the spreads against } \\
\text { Germany for eight euro } \\
\text { area countries (Belgium, } \\
\text { Ireland, Greece, Spain, } \\
\text { France, Italy, the } \\
\text { Netherlands and Portugal). } \\
\text { AR } 2008\end{array}$} & $\begin{array}{l}\text { Uwidacznia to Wykres B, } \\
\text { który przestawia rozpiętość } \\
\text { spreadów pomiędzy } \\
\text { obligacjami w Niemczech } \\
\text { i, odpowiednio, w ośmiu } \\
\text { krajach strefy euro (Belgii, } \\
\text { Grecji, Francji, Irlandii, } \\
\text { Włoszech, Holandii } \\
\text { Portugalii i Hiszpanii). }\end{array}$ & $\begin{array}{l}\text { Evoluţia este ilustrată de } \\
\text { Graficul B, care prezintă } \\
\text { spread-urile dintre } \\
\text { randamentele aferente } \\
\text { obligațiunilor de stat din } \\
\text { opt ţări din zona euro } \\
\text { (Belgia, Irlanda, Grecia, } \\
\text { Spania, Franţa, Italia, Ţările } \\
\text { de Jos şi Portugalia) faţă de } \\
\text { cele ale Germaniei. }\end{array}$ \\
\hline & Back Translation & Back Translation \\
\hline & $\begin{array}{l}\text { This is illustrated in Chart } \\
\text { B, which shows that spread } \\
\text { of the spreads between } \\
\text { bonds in Germany and, } \\
\text { respectively, in eight } \\
\text { Euro area countries } \\
\text { (Belgium, Greece, Spain, } \\
\text { France, Ireland, Italy, } \\
\text { The Netherlands, and } \\
\text { Portugal). }\end{array}$ & $\begin{array}{l}\text { This development is } \\
\text { illustrated in Chart B, } \\
\text { which presents the spreads } \\
\text { between government } \\
\text { bond yields of eight } \\
\text { Euro area countries } \\
\text { (Belgium, Ireland, Greece, } \\
\text { Spain, France, Italy, The } \\
\text { Netherlands and Portugal) } \\
\text { compared to those of } \\
\text { Germany }\end{array}$ \\
\hline
\end{tabular}

Analysis

The Romanian language version in Example 5 above features the same strategy as Examples 3 and 4: the English term is italicised and a hyphen is added to separate the English term from the Romanian inflection. The Polish language 
version, on the other hand, exhibits a very interesting new strategy - both the Polish equivalent word (rozpiętość) and the adapted English term are present. Therefore, a strange phrase rozpiętość spreadow ('the spread of spreads') is found in the document. This phrase appears in the 2008 Annual Report and could be interpreted as a transitional term, an attempt to integrate the loan word into the Polish economic vocabulary.

(6) Example 6

\begin{tabular}{|l|l|l|}
\hline \multicolumn{1}{|c|}{ EN language version } & \multicolumn{1}{|c|}{ PL language version } & \multicolumn{1}{c|}{ RO language version } \\
\hline $\begin{array}{l}\text { while sovereign spreads } \\
\text { vis-à-vis Germany widened } \\
\text { considerably for some } \\
\text { countries } \\
\text { AR 2008 }\end{array}$ & $\begin{array}{l}\text { Natomiast spready } \\
\text { (rozpiętości) obligacji } \\
\text { skarbowych wiektórych } \\
\text { krajach odbiegly } \\
\text { znacznie od poziomów } \\
\text { analogicznych obligacji w } \\
\text { Niemczech }\end{array}$ & $\begin{array}{l}\text { iar spread-urile aferente } \\
\text { obligațiunilor de stat faţă } \\
\text { de obligaţiunile emise de } \\
\text { statul german au crescut } \\
\text { semnificativ în unele ţări }\end{array}$ \\
\hline & \multicolumn{1}{|c|}{ Back Translation } & \multicolumn{1}{c|}{ Back Translation } \\
\hline & $\begin{array}{l}\text { In the meantime, spreads } \\
\text { (spreads) of government } \\
\text { bonds in some countries } \\
\text { have widened considerably } \\
\text { from the levels of the same } \\
\text { bonds in Germany }\end{array}$ & $\begin{array}{l}\text { while government bond } \\
\text { spreads grew significantly } \\
\text { in other countries } \\
\text { compared to the bonds } \\
\text { issued by the German state }\end{array}$ \\
\hline
\end{tabular}

Analysis

Once again, just as in Examples 3, 4 and 5 above, the Romanian language version features the same strategy for the integration of the loan word. The Polish language version, on the other hand, features both the English term and the Polish translation. It is interesting that while earlier examples (e.g. Examples 1 and 2 that come from Annual Reports 2006 and 2007) show that the English term was given in brackets after the Polish one, in this example, the Polish term is given in brackets and the English one is used as the main term. This indicates a shift from the equivalent Polish expression towards adopting the English term. The term SPREADS is also adapted to the rules of the Polish language: the plural ending is added (spready). 
(7) Example 7

\begin{tabular}{|c|c|c|}
\hline EN language version & PL language version & RO language version \\
\hline \multirow[t]{3}{*}{$\begin{array}{l}\text { Credit default swap (CDS) } \\
\text { spreads for government } \\
\text { bonds peaked and stock } \\
\text { markets reached a low } \\
\text { in March 2009. [...] The } \\
\text { favourable developments } \\
\text { reversed the trend in non- } \\
\text { euro area EU Member } \\
\text { States' CDS spreads, } \\
\text { money market rates and } \\
\text { stock markets. } \\
\text { AR } 2009\end{array}$} & $\begin{array}{l}\text { Spready swapów na } \\
\text { zwłokę w spłacie kredytu } \\
\text { (CDS) dla obligacji } \\
\text { skarbowych osiągnęły } \\
\text { najwyższe wartości, a } \\
\text { giełdy osiągnęły najniższe } \\
\text { poziomy w marcu } 2009 \\
\text { r. [...] Te pozytywne } \\
\text { czynniki odwróciły trend } \\
\text { dotyczący spreadów } \\
\text { swapów na zwłokę } \\
\text { w spłacie kredytu w } \\
\text { państwach członkowskich } \\
\text { UE spoza strefy euro, stóp } \\
\text { rynku pieniężnego oraz } \\
\text { giełd. }\end{array}$ & $\begin{array}{l}\text { Spread-urile CDS asociate } \\
\text { obligațiunilor de stat } \\
\text { au înregistrat un nivel } \\
\text { maxim, în timp ce piețele } \\
\text { bursiere au atins un minim } \\
\text { în luna martie 2009. [...] } \\
\text { Evoluţiile favorabile au } \\
\text { inversat trendul consemnat } \\
\text { de spread-urile CDS din } \\
\text { statele membre ale UE } \\
\text { din afara zonei euro, } \\
\text { randamentele pieței } \\
\text { monetare şi piețele bursiere }\end{array}$ \\
\hline & Back Translation & Back Translation \\
\hline & $\begin{array}{l}\text { Credit default swap (CDS) } \\
\text { spreads for government } \\
\text { bonds reached their } \\
\text { highest value and the } \\
\text { markets reached their } \\
\text { lowest levels in March } \\
2009 \text { [...] these positive } \\
\text { factors reversed the trend } \\
\text { for the credit default swap } \\
\text { spreads in EU member } \\
\text { states outside of the Euro } \\
\text { area, money market rates } \\
\text { and stock markets. }\end{array}$ & $\begin{array}{l}\text { CDS spreads for } \\
\text { government bonds reached } \\
\text { the maximum level whilst } \\
\text { the stock markets reached } \\
\text { the minimum level in } \\
\text { March } 2009 \text { [...] The } \\
\text { favourable developments } \\
\text { reversed the trend for CDS } \\
\text { spreads in EU member } \\
\text { states outside of the Euro } \\
\text { area, money market rates } \\
\text { and stock markets. }\end{array}$ \\
\hline
\end{tabular}

Analysis

The Polish language version exhibits unusual translation choices: this time, the English term is introduced with Polish inflections: spready/spreadow with plural nominative/plural genitive. The example comes from the 2009 Annual Report, in which the English term SPREAD* is used more than in other documents. Analysing examples from 2006 and 2007 through to 2009, it is possible to observe a trend: from a full translation, to the English term with the translation, to the English term only. However, from 2010 to 2013 the number 
of instances of spread in the Polish language version is much lower. The translators seem to revert back to the equivalent Polish expression rozpiętość, but the English expression is still present, albeit rarely. Such a development indicates that the Polish language versions gradually adopt loan words and make them an integral part of the Polish economic vocabulary, but the translator also has the choice to use the Polish equivalent expression.

The Romanian extract does not contain the term credit default swaps at all. Instead, it contains the abbreviation - CDS. This probably happens because the document already contains references to CDS and the term is provided in full - see the concordances for the string 'credit default swaps' presented in Figure 1. Just as in other examples, the English word is italicised in Example 7, while the Romanian inflection is not. This strategy (providing an abbreviated English term because the full term is provided earlier) has not been discussed in the literature. Providing the term swaps without a Romanian inflection is also rather uncommon. It could be argued that this happens due to the fact that the word swaps is part of the larger term credit default swaps.

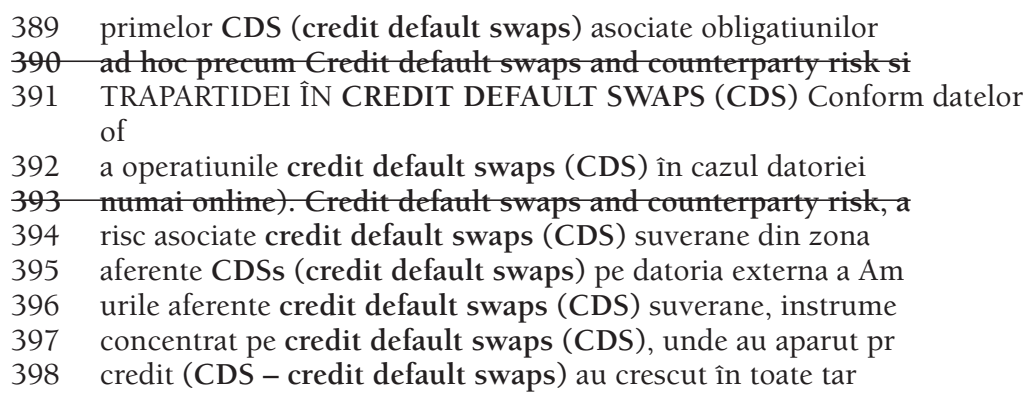

Figure 1. Concordance strings for the search string CDS. The strings that have been crossed out are irrelevant because they contain publication titles. 
(8) Example 8

\begin{tabular}{|c|c|c|}
\hline EN language version & PL language version & RO language version \\
\hline \multirow[t]{3}{*}{$\begin{array}{l}\text { This was reflected in } \\
\text { significant declines in } \\
\text { money market rates and } \\
\text { money market spreads. } \\
\text { More specifically, spreads } \\
\text { between secured and } \\
\text { unsecured money market } \\
\text { rates declined considerably } \\
\text { from their peaks in October } \\
\text { 2008, albeit remaining } \\
\text { elevated by historical } \\
\text { standards. } \\
\text { AR } 2009\end{array}$} & $\begin{array}{l}\text { W rezultacie znacznie } \\
\text { zmniejszyły się zarówno } \\
\text { stopy rynku pieniężnego, } \\
\text { jak też rozpiętości } \\
\text { pomiędzy nimi. W } \\
\text { ujęciu szczegółowym, } \\
\text { odnotowano } \\
\text { znaczące zbliżenie } \\
\text { stóp procentowych } \\
\text { zabezpieczonych i } \\
\text { niezabezpieczonych } \\
\text { transakcji rynku } \\
\text { pieniężnego. Rozpiętości } \\
\text { pomiędzy tymi stopami } \\
\text { - po osiągnięciu } \\
\text { wartości szczytowych w } \\
\text { październiku 2008 r. - } \\
\text { utrzymały się jednak na } \\
\text { podwyższonym poziomie } \\
\text { w ujęciu historycznym. }\end{array}$ & $\begin{array}{l}\text { Evoluţia s-a manifestat prin } \\
\text { diminuări semnificative } \\
\text { ale ratelor dobânzilor } \\
\text { pe piaţa monetară şi ale } \\
\text { spreadurilor aferente. } \\
\text { Astfel, spread-urile dintre } \\
\text { ratele dobânzilor garantate } \\
\text { şi cele negarantate s-au } \\
\text { îngustat considerabil } \\
\text { față de nivelurile record } \\
\text { consemnate în luna } \\
\text { octombrie 2008, deşi s-au } \\
\text { menţinut ridicate din } \\
\text { perspectivă istorică. }\end{array}$ \\
\hline & Back Translation & Back Translation \\
\hline & $\begin{array}{l}\text { As a result, there was a } \\
\text { significant reduction both } \\
\text { in the money market } \\
\text { rates and spreads between } \\
\text { money markets. More } \\
\text { specifically, a significant } \\
\text { decline in the secured } \\
\text { and unsecured money } \\
\text { market transaction rates } \\
\text { was noted. The spreads } \\
\text { between these rates, } \\
\text { however, stayed high by } \\
\text { historical standards after } \\
\text { reaching their peak in } \\
\text { October } 2008 \text {. }\end{array}$ & $\begin{array}{l}\text { The development was } \\
\text { visible in the significant } \\
\text { decline of the interest rates } \\
\text { on the money market and } \\
\text { of the respective spreads. } \\
\text { Thus, the spreads between } \\
\text { secured and unsecured } \\
\text { interest rates considerably } \\
\text { narrowed compared to the } \\
\text { record levels registered in } \\
\text { October 2008, although } \\
\text { they remained high from a } \\
\text { historical perspective. }\end{array}$ \\
\hline
\end{tabular}

Analysis

In the Polish extract, a simple strategy of translating the expression with an equivalent linguistic expression has been chosen. The text was produced in 2009 (the year when the English term spread occurred most frequently in the Polish language corpus) and it can be seen that the Polish translator chose a Polish expression over the adoption of a foreign term, while the Romanian 
language version clearly favours the English expression and integrates it into the language. This is very different from Example 7 above, which also comes from the 2009 Annual Report. Once again, this variety within the same document suggests that there was no universally accepted and institutionally or linguistically regulated way to translate the term and the translators were in the process of searching for the right way to render it in the target language.

In the Romanian extract, the word spread is spelt once with a hyphen and once without it: spreadurilor (the definite article, genitive case), spread-urile (the definite article, nominative case). This indicates that the term is so new in the Romanian economic vocabulary that in 2009 there was still no consistent, established way of using it in writing and the translators were engaged in the process of 'creative searching'. In Romanian, the rules of spelling foreign words are the following: if the final part of the word is pronounced the way it is written, no hyphen is added when the word has a definite article (bossul, linkul, weekendul); if the final part of the word is pronounced differently than how it is written (according to the rules of phonetic writing), a hyphen is added (mouse-ul, site-ul) because the final $\mathrm{E}$ of both words is not pronounced. However, perhaps, due to the novelty of the term, hyphenation is preferred for the term spread* in the entire Romanian corpus even if the final sound of the word is pronounced as it is written.

\section{Conclusion}

This study has analysed the strategies for the adoption and adaptation of English loan words in the Romanian and Polish languages, in texts published by the European Central Bank. Mixed research methods (quantitative and qualitative) were used, and the results produced by the qualitative analysis correlate with those of the quantitative analysis, revealing interesting results that could not be found using solely quantitative methods. It was found that the Polish and Romanian economic documents analysed in the present study contain a large number of English loan words, which are adapted and inflected according to the conventions of each language. For instance, in Romanian, the definite article and/or plural forms are added to the English word: swapurilor; spread-urile, etc., or in Polish, case inflections and plural forms are added: swapami, spreadów, etc. Although the English loan words as economic terms are integrated (adopted and adapted) into the Polish and Romanian languages, it is not possible to claim that the process is seamless and the words are fully incorporated. Sometimes, additional explanatory terms are introduced (e.g. 'swap transactions', 'swap operations'). Word class can also be changed: the noun swap becomes an adjective (swapowy) in Polish. Finally, 
based on the analysis of the language versions, it is possible to conclude that Romanian economic vocabulary tends to be more open towards the introduction of loan words than the Polish one.

There could be multiple reasons for the use of these strategies: institutional requirements (as discussed by Koskinen, 2008), requirements set by national language institutes or personal preferences (cf. Tcaciuc, 2015). Koskinen (2008) conducted ethnographic research and interviewed translators in the European Commission; her research suggests that the institution has a strong influence on translation choices. Tcaciuc (2015), who explored translation practices at the ECB, used a corpus-based approach and questionnaires; her research indicates that the translators make choices but are also influenced by institutions and the rules of the language into which they translate.

Both Polish and Romanian also seem to be looking for creative ways to integrate the loan words: the Polish language version moves from the equivalent Polish expression to both the equivalent expression and the English term with Polish inflections, to the adapted English term only; the Romanian language versions contain hyphenated and non-hyphenated forms with and without italics. This indicates that both languages are searching for ways to adopt and adapt loan words that are an integral part of the fast-evolving economic vocabulary.

\section{References}

FISIAK, Jacek. (1970) "The semantics of English loanwords in Polish." Studia Anglica Posnaniensia 2, pp. 41-49.

Kochman-HaŁadyJ, Bozena. (2001) "English Loanwords in Polish Business as a Result of American Economic Globalization." Studia Anglica Resoviensia 2, pp. $40-44$.

Koskinen, Kaisa. (2008) Translating Institutions. An Ethnographic Study of EU Translation. Manchester: St Jerome Publishing.

KULESZA, Barbara. (2010) "Najnowsze anglicyzmy w języku prasy młodzieżowej." [The Newest English Loan Words in the Discourse of Youth News Media]. Kwartalnik Jezzykoznawczy, 3-4.

MANEA, Constantin. (2005) "Remarks on the Recent English Loanwords in the Romanian Vocabulary of Economics." The Proceedings of the EUROPEAN INTEGRATION-BETWEEN TRADITION AND MODERNITY Congress, Editura Universităţii "Petru Maior", vol. 1, Petru Maior University, pp. 365-370. Electronic version available at: <http://www.upm.ro/ 
facultati_departamente/stiinte_litere/conferinte/situl_integrare_europeana/ Lucrari/ConstantinManea.pdf>

Militaru, Petrişor. (2008) "English Influences in Romanian Business Vocabulary." Journal of Applied Economic Sciences III:2, pp. 65-70

OtwinowsKa-KaszTElanic, Agnieszka. (2000) A Study of the Lexico-Semantic and Grammatical Influence of English on the Polish of the Younger Generation of Poles. Warszawa: Wydawnictwo Akademickie DIALOG.

RUS, Laura Maria. (2005) "Un fapt lingvistic de actualitate: influenţa engleză asupra limbii române." [A Current Linguistic Fact: the English influence on the Romanian Language]. The proceedings of the international conference "Integrarea europeană între tradiţie şi modernitate", Tg-Mureş, pp. 266-272.

SzTENCEL, Magdalena. (2009) "Boundaries Crossed: The Influence of English on Modern Polish.” E-Pisteme 2:1, pp. 3-17.

TCACIUC, Luciana Sabina Mihaela. (2015) Translating Metaphors from English into Romanian in Economic Documents. Iasi: Lumen Publishing House.

TRĂISTARU, Laura. (2008) "Moda anglicismelor în limba română." [The Trend of Using English Loan Words in Romanian]. Distorsionări în comunicarea lingvistică, literară si etnofolclorică românească si contextul European, 25-27 September 2008, Iaşi, pp. 721-725. Electronic version available at: <http://academiaromana-is.ro/philippide/distorsionari_2008/721-725\%20Traistaru\%20 Laura\%20rev.pdf>

WiĘCŁAWSKA-SZYMAŃSKA, Edyta. (2009) "Lexical Importation and Integration: The Case of English-rooted Polish Legalese." Skase Journal of Theoretical Linguistics 6:2, pp. 39-52. Electronic version available at: <http://www.skase. sk/Volumes/JTL14/pdf_doc/03.pdf>

Witalisz, A. (2006) "English linguistic influence on Polish and other Slavonic languages." Quaderni del Centro di Studi Linguistico-Culturali, Occasional Papers del CeSLiC, Alma Mater Studiorum Università di Bologna Digital Library. Electronic version available at: <http://amsacta.cib.unibo.it/918/>

\section{BIONOTE}

LUCIANA SABINA TCACIUC holds an MA in Translation and Interpreting from Alexandru Ioan Cuza Univesity, Iasi, Romania, and a PhD in Translation Studies from Aston University, Birmingham, UK. She has taught at Aston University and the University of Birmingham and presented her research at various international conferences. She also has extensive experience in translation and interpreting, particularly EU translation and public service interpreting. Her research interests are: metaphor translation, translating economic texts, institutional translation, EU translation, and translating idioms. 
LUCIANA SABINA TCACIUC est titulaire d'une maîtrise en traduction et interprétariat de l'Université Alexandru Ioan Cuza, Iasi, Roumanie, et d'un doctorat en traductologie de l'Université d'Aston, Birmingham, Royaume-Uni. Elle a enseigné à Aston University et à l'Université de Birmingham et a participé aux diverses conférences internationales. Elle possède une vaste expérience dans la traduction et l'interprétation, et en particulier la traduction des documents de l'Union européenne. Parmi ses intérêts de recherche notons: la traduction de la métaphore, la traduction de textes économiques, la traduction institutionnelle, la traduction de l'UE, et la traduction des expressions figées.

VLADISLAV MACKEVIC holds a BSc in English and International Relations from Aston University, an MA in Translation from the University of Bristol and is currently a PhD student at Aston University, Birmingham, UK. He has worked in teaching and research positions at Aston University and the University of Birmingham. His research interests include forensic linguistic analysis, sociolinguistics, and comparative linguistics.

VLADISLAV MACKEVIC est titulaire d'une licence en anglais et relations internationales de l'Université d'Aston, et d'une maîtrise en traduction de l'Université de Bristol et est actuellement doctorant en linguistique à l'Université d'Aston, Birmingham, Royaume-Uni. Il a donné des cours et a travaillé en tant que chercheur à l'Université d'Aston à l'Université de Birmingham. Ses intérêts de recherche comprennent la linguistique légale, la sociolinguistique et la linguistique comparée. 